\title{
Human Capital Investment: The Datai Sets a Risky Example
}

\author{
Rozila Ahmad * \& Roshita Abdul Razak \\ School of Tourism, Hospitality and Event Management, Universiti Utara Malaysia, \\ Sintok, Kedah, Malaysia
}

Received: $21 / 4 / 2020$

Revised: $14 / 6 / 2020$

Accepted: 18/6/2020

Published: $30 / 6 / 2020$

\begin{abstract}
Human capital investment is important for service firms that provide personalised services, for example, luxury hotels. Hotels in Langkawi claim that they conduct continuous training. The extent of the training is just sufficient to fulfil the Ministry of Human Resources training requirements. Rarely do businesses spend above the minimum requirement. This is especially true in the hotel industry, an industry that many perceive as a stepping stone in building their careers. This makes it significant to conduct and in-depth interview with the master minds of The Datai Investing in People (DIP) training programme. The purpose of the interviews is to investigate how human capital investment is carried out in the hotel industry. Furthermore, the fact that covid-19 spreads around the world only a year after the "new" Datai reopens makes it seems riskier as it is very doubtful that the hotel will get the expected returns from its investment. The findings of this study may enhance understanding of human capital investment in the hotel industry as it provides in-depth explanation of how The Datai invests in its human capital. The finding will also bridge the gap between theory and practice as it enhances understanding of why many hotels choose to limit their human capital investment. The Datai's sacrifice makes it clear why it has remained as the employer of choice.
\end{abstract}

Keywords: Human capital investment, training, human resource management, talent

\subsection{Introduction}

The Datai Langkawi is one of the world's most stunning resorts. It is located in Langkawi's 10-million-year old rainforest that is rich in wildlife and faces The Datai Bay. The Datai has 121 rooms, villas and suites. Owned by Khazanah Nasional Berhad and managed by Themed Attractions Resorts and Hotels Sendirian Berhad. The Datai is well known for its surrounding nature, architecture, food and beverage services, spa

* Corresponding Author Email: rozila@uum.edu.my 
and other services. The hotel is also well known for its personalised services (The Datai Langkawi, 2018). It has been the employer of choice in Langkawi for many years (Ahmad, Solnet \& Scott, 2010). The Datai compensates its employees handsomely and its employee turnover is very low compared to other hotels. Although it is a locally owned independent hotel, it is a hotel that even those from outstanding international chain hotels are keen to join.

The Datai Langkawi is the first hotel in the South East Asian region to spend as much as RM2.5 million on 'Datai Investing in People' program. The custom-designed training ends with Hospitality certification which is meant to enhance staff motivation, inspiration and service excellence to match with the new image of the hotel. Interior and exterior renovation of the 25 years old hotel costs USD60 million and took 10 months; it was completed in July 2018 (Datai Langkawi, 2018). The training was conducted throughout the renovation period. The renovation and the investment in human capital is The Datai's initiative to revive its legend. However, beginning December 2019, the Covid-19 outbreak has dampened the world's economy and hotels around the globe have suffered due to travel bans. This indicates that human capital investment is risky especially in a business entity that is very volatile to environmental changes. The fact that hotel industry has a high employee turnover makes it even riskier. While it is too early to investigate whether The Datai has reaped the expected returns from its investment, it is the right time to investigate the hotel's human capital improvement initiative.

The study of human capital investment in the Malaysian hotel industry is still at its infancy. Exhaustive literature searches on articles using "human capital" as the keyword discovered only two studies of hotels in Malaysia and eighteen studies of hotels in other countries. However, none of the studies clearly define human capital investment. This is understandable given the fact that the hotel industry has a very high employee turnover (Abo-Murad \& Al-Khrabsheh, 2019). However, the importance of developing talents by enhancing the human capital of an organization should not be overlooked (Alferaih, Sarwar \& Eid, 2018).

Worldwide, existing studies related to human capital in the hotel industry discussed the importance of human capital as the main factor of productivity (Stauvermann \& Kumar, 2017), human capital's influence on economic growth (Fahimi, Akadiri, Seraj, \& Akadiri, 2018) and innovation (Ferrary, 2015), human capital and value creation (Ifleh, Lotfi, \& Elkabbouri, 2017), human capital and strategic orientation (Walsh, Enz \& Canina, 2008) and human capital development (Adeola, 2016). In Malaysia, Kaliappen and Hilman (2014) investigated the relationship between motivational factors and employees' motivation and discovered that 'salary', 'fringe benefit' and 'interesting job' were among the most popular motivational factors. The authors concluded that commitment on this motivational factors will result in human capital 
having a strategic role in helping Malaysia to position itself in the world of hospitality business. Abdullah, Mat-Isa, Arshad, Hamzah and Hashim (2013) explores Malaysian hotels' knowledge management strategies and discovered that those with higher ratings are more likely to adopt a human oriented strategy. This influences the innovativeness and creativeness of their human capital and consequently increases their competitive advantage. Abdullah et al'.' (2013) findings is consistent with SHRM and the Theory of Human Capital. However, studies that clearly define and holistically demonstrates the practise of human capital investment in the Malaysian hotel industry are yet to be conducted.

To fill the gap in the literature on human resource management in the tourism and hospitality industry, this study seeks to answer the following research questions:

1. What is the definition of human capital investment in the hotel industry?

2. How does The Datai invests in its human capital through DIP training program?

This study is significant as it reveals private sector active participation in ensuring employees' growth and prosperity by accelerating human capital development. Thus, it supports Eleventh Malaysia Plan (2016-2020) which stresses the importance of retaining human capital especially among native workers in the service industry.

\subsection{Literature Review}

Solid human capital management is important because it improves organizational performance, corporate profits and create shareholders' value (Felicio \& Couto, 2014; Walsh, Enz \& Canina, 2008; Warech \& Tracey, 2004). Human capital can be defined as an individuals' knowledge, experience, professional competency and cognitive ability (Felicio \& Couto, 2014). It also includes employees' training, education, and creativity (Ferrary, 2015; Gates \& Langevin, 2010). Money spent on training is considered an investment (Mohammed et al., 2013). While the definition of human capital investment in Human Resource Management literature is scarce, Strategic Human Resource Management literature defines human capital investment as all costs related to eliciting productive behaviours from employees including those related to motivating, monitoring and retaining them (Jackson \& Schuler, 1995; Lepak \& Snell, 1999). In the hotel industry, human capital investment is yet to be properly defined by hotel managers.

Human capital is a necessity to luxury hotels but not for low cost hotels offering low level services because their customers are looking for basic services such as a clean and simple hotel property at a low price (Walsh et al., 2008). Similarly, the Human Capital Theory postulates that human capital investment is of less significance for 
small employers as their practise of promoting internal employees to higher positions rather than recruiting externally does not requires them to invest in human capital. Furthermore, they do not provide enough job security and career opportunities to attract and retain employees with high capacities (Ferrary, 2015).

It is more effective to invest in employees who have a high general mental ability and a strong desire to grow (Judge, Klinger, \& Simon, 2010; Sarkawi, Jaafar, Shamsuddin, \& Abdul-Rahim, 2016). Studies have shown that smarter individuals are more likely to experience career growth. They are promoted and their salary is increased as a result of the competencies they acquired. They have attained higher education, completed more job trainings and handled more complex activities (Judge et al.,2010). Similarly, they have attained more accomplishments, learning and professional development on the job (Sarkawi et al., 2016). This helps to ensure return on investment. Employees with strong growth needs strength tend to develop strong internal motivation when working on complex and challenging jobs (Sarkawi et al., 2016). Employees motivation is a factor necessary for their performance (Shahzadi, Javed, Pirzada, Nasreen, \& Khanam, 2014). In addition to enhancing employees' performance, human capital investment can also encourage them to adjust their skills and knowledge to organisational needs (Nieves \& Quintana, 2018).

Human capital influence organizational performance (Felicio \& Couto, 2014; Walsh et al., 2008). Annual income statement can be used to measure firm performance (Walsh et al., 2008). Thus, it can also be used to assess the returns on human capital investment. However, assessing the returns on human capital investment is not the purpose of this study.

\subsection{Methodology}

The qualitative method was used to answer the research questions investigated in this study. The qualitative approach is a form of interpretive inquiry that helps the researcher to develop a complex overview of a phenomena and explain the it holistically (Creswell, 2014). While research question one is answered based on interviews with Human Resource managers from four luxury hotels in Langkawi, research question two is answered using a single case study. Human capital investment is defined based on the answers given by managers from Human Resource Department. Various perspectives were sought in order to obtain an extensive definition. Qualitative single case study was used for thorough understanding of how The Datai invests in its human capital. Single case study is an intensive study and is the preferred strategy when "how" or "why" questions are posed, when the investigator has little control over events and when the focus is on contemporary phenomena (Yin, 2009). Table 1 lists the respondents' profiles. 
Table 1

Respondent's Profile

\begin{tabular}{lcclll}
\hline State & $\begin{array}{c}\text { Total luxury } \\
\text { Hotels }\end{array}$ & Participant & Designation & Experience & Name \\
\hline Kedah & 7 & 4 & HR Director & 8 years & HRD1 \\
& & & HR Director & 30 years & HRD2 (Datai) \\
& & & HR Director & 11 years & HRD3 \\
& & & Training Executive 23 years & TE4 \\
\hline
\end{tabular}

\subsection{Findings}

\subsection{Definition of Human Capital Investment}

The main elements of human capital investment are employee training and career development. According to HRDK3, "Human capital investment is investment in the training of our people, building platform for them to build their career and continuously helping them to grow." This definition of human capital investment is consistent across all managers interviewed. According to HRDK2, "Human capital investment is not just money, it has a lot to do with effort, drive and passion" and it focus on "people with high potential or the good performers who want to move up the ladder." HRDK1 links human capital investment with the guests.

Human capital investment is where we can upgrade our employees. We employ, we train, we provide them with the right skills and tools for them to improve. Whatever they learn from the training will make them better and they can provide better services, and makes guests happier, and then we will get the return. The guests will return. Usually when guests return, it is not just because of the hotel. Of course it is also a part of it, but most of it is because of the staff. Because they know they have someone they can trust at the hotel. I have this experience when there was an Arab looking for a staff who has left to work at another hotel. Then, this Arab went looking and stayed at the hotel where our ex-staff is working. The guest sees the staff as a friend and someone he trusts. The guest said he never encounter any problem with the staff. The staff takes good care of him. (HRDK1)

Compensation is not considered as an element of human capital investment even though it is crucial to provide valuable employees with an attractive and competitive compensation package in order to retain them with the organization. According to the 
managers interviewed, compensation is short-term whereas human capital investment is long-term. Even HRD2, the hotel with the best compensation in Langkawi disagreed with the idea that compensation is part of human capital investment even though it can help retain employees.

When we signed the CA, the union says we are the best in terms of compensation in Malaysia. The lowest paid is RM1000 (basic pay) and they have service charge (service point) and all other benefits spelled in the collective agreement... Human capital investment is not just money, it has a lot to do with effort, drive and passion. Whoever is the manager, not just HR. If you are the direct report, you are responsible for the person's training and development. Training is short term. Human capital development is long term. It is more holistic, less technical component, concerns on the person career growth. Training, I train you to do the job, so you are the trained employees. Human capital development is whether I am preparing you for the next level, preparing you to become more allrounder, somebody who knows the organization well, who move forward, who is more receptive to change as well as personal development. The Datai spends RM2.5 million on training but the money is a small thing. If you pay the person well but he is not motivated to develop himself, it is just...(HRD2 did not finish his sentence)... human capital development is a lot to do with people with high potential. Good performers who also want to move up the ladder. To retain them, that's salary and compensation. You need to have a good pay scheme to attract people. The link between good pay, structured pay, salary and compensation policy. The link between human capital investment and compensation. We compensate them accordingly. At the same time this people don't just look at the salary and compensation. People with high potentials want challenges in their career. The career growth comes with the salary... Butler is a very glamorous job, big tips, that gives satisfaction at the end of the day. They serve people with high status in the society. They have status, money, influence. When you mix around with this people...(pause)... ask the butler what is the best side of serving this people. It is how they think, how they talk, their habits. Taking money out of that... human capital development. I want to develop that. I don't want to develop what is short term. (HRD2)

TE5 further justifies why compensation should not be regarded as an element of human capital investment. At the same time, her justification indicates that human capital investment is risky. 
Hotel line is very challenging. Sometimes they get better offer then they jump to another property. So, the turnover can be quite high. The industry can be very competitive when new hotels come on board. Finding people is also difficult on the island. Maybe because of different timing. So, people don't want to...(TE4 did not finish her sentence)... Other company will counter offer them. You can counter offer them. Other hotels can offer them double. (TE4)

In conclusion, human capital investment is all the costs related to human capital development. It includes training and career development of self-motivated, dedicated and high performance employees with the objective of enhancing organization performance. Additionally, it is crucial for human capital investment to be accompanied with attractive and competitive compensation.

All four hotels invests in their human capital through employees training and development. According to the managers, it is very important to invest in human.

We have full time training manager whose focus is only on people development and enhancing their skills and on what we will do next. And we have plans of what we need, what we will do, what is required from corporate office. That is absolutely human capital investment. It is very important for us because, to be successful, we need to invest in human. (HRDK3)

For some training conducted, hotels can claim from Human Resource Development Fund provided that they have contributed to the agency which is under the Ministry of Human Resources, Malaysia. TE4 stated, "Our hotels have our target each year. We must have 50 hours per person. About 10 hours per person per month. Some training we can claim from HRDF fund."

However, none of the hotels invests in their human capital as much as The Datai.

It could be anything such as on the job training or specialised training like the Certified Hospitality Revenue Management that we conduct for the managers. The Food and Beverage specialised skill training that we conduct for rank and file. Either we provide in house training or we send them outside. We always give more training hours. The more the better because it is needed...The Datai goes for extensive training program. That is the way to go. You have to. They have to make sure their employees are perfect during reopening. If we have the money, why not? (HRDK1) 


\subsection{Human Capital Investment at The Datai}

At The Datai, in addition to the investment in human capital development activities that have become a routine for many luxury hotels, there was also DIP training program. DIP training program was conducted during the hotel's closure for renovation. Instead of terminating, asking employees to take unpaid leave and deducting employees' pay, they were sent for training. Voluntary Separation Scheme was offered to those nearing retirement age and with poor medical conditions. Those qualified for the training are bound with a contract that requires them to remain with the organization for a certain period of time. This is to ensure that the human capital remains with the organization until the costs of training is covered.

The Datai developed a special training program to ensure that it is effective and it will serve the organization's needs which includes hotel's profitability and employee's personal growth. DIP training program is customised to The Datai's needs and it was preceded with a detailed and careful planning. The planning process involves thorough observation, discussion and analysis of pre-training situation.

When you talk about human capital development, it should be tailor made and not something off the shelf or something you think might be good. The more you probe, the more symptoms you will get and the better the diagnoses. Then you can accurately suggest. When it's a group, it can't be tailor made and the focus should be on the organization's needs. At the same time, you can also do a matrix, take a sample, do a good sampling and see the trend. You also have to see how it happens behind the scene. Check-in to the hotel, spend the time at the hotel, observe and talk to everybody involved. Talk with the guests, the staff, the GM. The GM will give a more long termed and business oriented perspective. HR will move towards more human capital; department heads will give from divisional perspectives. So you will get all rounded feedback. It Must take a 360 degrees approach. For the participants, it should be...(HRDK2 did not finish his sentence)... If not they would be wondering what is there for me, I don't think this is what I need. This would help them to be there, to participate, to stay focused. The majority would 'yes, this is what I want, I need this. It should be something very useful and meaningful for their career. When I do training, I always link the objective with what is there for me. Otherwise people are not keen to learn. What benefits do I get if I learn this?

The duration of DIP program was between five to seven months. It combines academic and field-related modules. To conduct the program, The Datai collaborated with 
three higher-educational institutions, Universiti Utara Malaysia, Langkawi Tourism Academy and Taylors University. The DIP program was professionally carried out. All employees under training were given a booklet that provides detail information on DIP programs including motivational messages from the General Manager and HR Director. The following are the messages as printed in The Datai training booklet.

As we closed our doors momentarily to make way for the "Restoration" work on our hardware, we did not forget to invest on our Software - the one that makes our guest emotionally connected to The Datai Langkawi. I would like to congratulate you for being one of the successful participants in our very unique and special Certification Education Program called Datai Investing in People or DIP. I am proud to share with you that this initiative is an unprecedented field-related education programme in Malaysia at least and very well received by all parties - Our Guest, our Board of Directors, our very own Leadership Team at The Datai Langkawi and, most importantly, you as the participant. I sincerely hope and believe that you will take full advantage of this huge investment in Human Capital Development by showing your commitment and participation. Indeed, the first beneficiary of this unique programme is yourself so do make the most of it. (Arnaud Girodon, General Manager, p.3)

The Datai Investing in People or DIP was conceived having in mind that the best initiative and 'gift' for our people is Education. During one of our Town Hall Meetings, there was a question from the floor about 'Bonus'. My spontaneous and sincere answer was "the best 'Bonus' parents offer their children is investing in their education". I could see nods all around the Dining Room. To me, this is a clear approval, agreement and commitment from our Stakeholdesr - Our People. On several General Manager's cocktail sessions, which I attended, our guests were surprised and very delighted to learn that, not only The Datai Langkawi is sustaining our people during the closure period but also enrolling them into a Special Education Program. Hearing this from the horse's mouth is very assuring and motivates me and my team to give the best! The support from our Board of Directors, with full backing from our top management at the Hotel level, certainly show that our efforts are valued and truly appreciated. All the above true stories would not be meaningful if this opportunity is not fully taken by you - The Chosen One. I assure you that the modules in store for you is going to be very exciting and enjoyable too. I have confidence that you will put your best effort and passion as you have been putting at work during this 5 months golden opportunity. Lastly, a wealth of knowledge is a good weapon for our restored The Datai Langkawi moving forward. (Johan E Abdullah, Human Resource Director, p.4) 
The objectives of DIP program was also clearly stated in the 27 pages DIP training program booklet. In general, the objectives of the program are to groom staff members to continue to deliver service excellence and to provide employees with the opportunity to grow and excel. The specific aims for the employees are: to upgrade employee's education, knowledge, skills and attitude and to boost their self-esteem. As for The Datai, the aims are: to enhance its status as employer of choice, to add value to the company's Outreach Program and to promote positive image of the company.

The DIP programme is customised to effectively train two different categories of employees, supervisory and management, and rank and file (non-management). In addition to indoor training, there were also outdoor fun activities held at local tourist destinations for both groups of employees.

The Executive Advance Certificate in Hospitality Management was designed for supervisory and management staff. It is based on the idea of The Datai's General Manager who envisions the hotel as the best in its class by improving its supervisory and management skill and inculcating The Malaysian Hospitality brand. It echoes Khazanah Nasional Berhad's theme "Living our values" by inviting Perbadanan Kemajuan Kraftangan Malaysia to collaborate in handling activities that values Malaysian traditions, arts and culture. The curriculum also emphasize on work related concepts and cross-departmental exposure. The Executive Advance Certificate in Hospitality Management started on 22 October 2017 and ended on 5 April 2018.

Certification in Education Programme was designed for rank and file employees to support them in delivering The Datai's standard by enriching their industrial knowledge, technical capabilities and soft skills. The programme focused on three core departments, Room Division, Culinary and Food and Beverage. Certification in Education Programme started on 26 October 2017 and ended on 3 May 2018.

The DIP training program booklet ends with a guideline that lists the "Dos" and "Donts" throughout the training. In summary, the guideline reminds employees to be well disciplined, focused and committed to the training program.

\subsection{Discussion}

The Datai's initiative to invest in human capital is consistent with the Strategic Human Resource Management (SHRM) literature and Theory of Human Capital (Jackson \& Schuler, 1995; Lepak \& Snell, 1999; Walsh et al., 2008). SHRM literature highlights the importance of the synchronization of all human resource elements. It begins with thorough employee selection. Training requirements is assessed based on employees' 
performance appraisal (Jackson, Schuler \& Jiang, 2014). The performance appraisal should be fair and objective so that true talents with potential could be identified and send for suitable trainings (Lepak \& Snell, 1999). Employees training should match their level of general mental ability and growth needs. While those with higher level of general mental ability and growth needs are sent for management training which requires them to do complex tasks, those with lower general mental ability and growth needs strength are sent for trainings to improve routine daily operational tasks (Judge et al., 2010; Sarkawi et al. 2016). To retain the valuable employees, it is crucial to practise compensation based on performance (Martocchio, 2015).

Human capital investment in hotel industry is risky. Hotel business is highly susceptible to changes in its environment such as changes in the economy (Walker, 2017). The covid-19 outbreak has resulted in many hotels experiencing revenue loss as people have stopped traveling. When there is no revenue, it is difficult to get returns on investments. Furthermore, the hotel industry is well known for high employee turnover. Competition in the industry is high and it is common for an employee to move from one hotel to another for better salary and position (Alferaih, Sarwar \& Eid, 2018). In fact, it is acknowledged as the path hoteliers need to walk through in order to build their career in the industry. New luxury or high rating hotels prefer employing experienced employees from other hotels as they are already trained human capital. Obtaining ready-made talents has many advantages. Firstly, these talents have worked in the hotel industry and they have the spirit and energy to remain in the challenging industry. Secondly, they can attract other talents to the new hotel. Most importantly, they can also attract the satisfied guests they have served to be the guests of the new hotel. Thus, it is crucial for hotels that invest in their human capital to retain their talents by compensating them accordingly while ensuring their satisfaction and commitment to the organization (Kandampully, 2007). They should avoid from losing valuable employees to competitors (Lepak, Smith \& Taylor, 2007).

High investment in human capital is essential to service firms that provide customized services and seek to compete based on their services but not to firms that provide basic services at minimal cost (Walsh et al., 2008). Based on Warech and Tracey (2004), solid human capital management refers to a well-designed and implementation of job-skill training. This implies that luxury hotels should invest in designing and implementing their employees' job-skill training in order to develop their human capital and enhance organization's performance. As cautioned by Warech and Tracey (2004), not all human resource practices and trainings create values. Thus, the effectiveness should be evaluated. 


\subsection{Conclusion}

This study contributes to theory and practice. The findings of the study define and reveal elements of human capital investment. Prior to this study, human capital investment definition within the context of Tourism and Hospitality industry is scarce. Most importantly, this study provides in-depth explanation of human capital investment in a prestigious hotel as the context of study. It may serve as an example to other luxury hotels that intend to enhance their human capital and retain their talents.

This study has two limitations. Firstly, the details of employees training and career development activities at The Datai is not laid out in this article as it has been discussed in previous literature without mentioning names of the hotels (Ahmad et al., 2010). Secondly, this is a cross-sectional qualitative study that merely explores hotels investment in human capital. Thus, the findings of this study cannot be generalised. Therefore, it is beneficial to conduct a longitudinal study that quantitatively measures the returns of human capital investment in the future.

\subsection{Acknowledgement}

This study is funded by Fundamental Research Grant Scheme.

\section{References}

Abdullah, N. L., Mat-Isa, R., Arshad, R., Hamzah, N., \& Hashim, N. A. (2013). Knowledge management strategy and human capital management in hotel industry. Jurnal Pengurusan, 38, 3-14.

Abo-Murad, M. \& Al-Khrabsheh, A. (2019). Turnover culture and crisis management: Insights from Malaysian hotel industry. Academy of Strategic Management Journal, 18(2), 1-14.

Adeola, O. (2016). Human capital development in the hospitality industry in Nigeria. Worldwide Hospitality and Tourism Themes, 8(2), 149-157.

Ahmad, R., Solnet, D. \& Scott, N. (2010). Human resource practices system differentiation: A hotel industry study. Journal of Hospitality and Tourism Management, 7, 84-94.

Alferaih, A., Sarwar, S., \& Eid, A. (2018). Talent turnover and retention research: The case of tourism sector organisations in Saudi Arabia. Evidence-based HRM: A Global Forum for Empirical Scholarship, 6(2), 166-186.

Creswell, J. W. (2014). Research Design: Qualitative, Quantitative \& Mixed Methods Approaches (4th ed., pp. 1-273). London: Sage Publications. 
Felicio, J. A., \& Couto, E. (2014). Human capital, social capital and organizational performance. Management Decision, 52(2), 350-364.

Fahimi, A., Akadiri, S. S., Seraj, M., \& Akadiri, A. C. (2018). Testing the role of tourism and human capital development in economic growth. A panel causality study of micro states. Tourism Management Perspectives, 28, 62-70.

Ferrary, M. (2015). Investing in transferable strategic human capital through alliances in the luxury hotel industry, Journal of Knowledge Management, 19(5), 10071028.

Gates, S., \& Langevin, P. (2010). Human capital measures, strategy and performance: HR managers' perceptions. Accounting Auditing and Accountability Journal, 23(1), 111-132.

Ifleh, Y., Lotfi, M., \& Elkabbouri, M. (2017). Rethinking value creation from the resource based view: The case of human capital in Moroccan hotels. International Journal of Applied Management and Economics, 2(2), 13-25.

Jackson, S. E., \& Schuler, R. S. (1995). Understanding human resource management in the context of organisations and their environments. Annual Review of Psychology, 46, 237-264.

Jackson, S. E., \& Schuler, R. S., \& Jiang, K. (2014). An aspirational framework for Strategic Human Resource Management. The Academy of Management Annals, $8(1), 1-56$.

Judge, T. A., Klinger, R. L., \& Simon, L. S. (2010). Time is on my side: Time, general mental ability, human capital, and extrinsic career success. Journal of Applied Psychology, 95(1), 92-107.

Kaliappen, N. and Hilman, H. (2014). Strategic roles of human capital in transforming hotel industry in Malaysia. Journal of Global Business Advancement, 7(3), 222-235.

Kandampully, J. (2007). Service management: The new paradigm in hospitality. New Jersey: Pearson Education.

Lepak, D. P., Smith, K. G., \& Taylor, M. S. (2007). Value creation and value capture: A multilevel perspective. Academy of Management Review, 32(1), 180-194.

Lepak, D. P., \& Snell, S. A. (1999). The human resource architecture: Toward a theory of human capital allocation and development. Academy of Management Review, 24(1), 31-48.

Martocchio, J. J. (2015). Pay, Compensation, and Performance, Psychology of. International Encyclopedia of the Social \& Behavioral Sciences: Second Edition (pp. 611-617). Elsevier Inc.https://doi.org/10.1016/B978-0-08-0970868.22012-6

Mohammed, J., Mitho, K. B., Jariko, G. A., \& Zehri, A. W. (2013). Importance of human resource investment for organizations and economy. Journal of Managerial Sciences, 7(1), 127-133. 
Nieves, J. \& Quintana, A. (2018). Human resource practices and innovation in hotel industry: The mediating role of human capital. Tourism and Hospitality Research, 18(1), 72-83.

Sarkawi, M. N., Jaafar, A. R., Shamsuddin, J. \& Abdul-Rahim, N. F. (2016). Moderating effect of growth need strength on the relationship between job characteristics and job satisfaction. International Review of Management and Marketing, 6(8S), $1-8$.

Shahzadi, I., Javed, A., Pirzada, S. S., Nasreen, S., \& Khanam, F. (2014). Impact of employee motivation on employee performance. European Journal of Business and Management Online, 6(23), 159-166.

Stauvermann, P. J. \& Kumar, R. R. (2017) Productivity growth and income in the tourism sector: Role of tourism demand and human capital investment. Tourism Management, 61, 426-433.

The Datai Langkawi. (2018). The rebirth of a legend: The Datai Langkawi unveils its new look. Retrieved on $8^{\text {th }}$ April 2020 from: https://www.thedatai.com/ media/1236/press-release-tdl-rebirth-of-a-legend mar-1.pdf

Walker, J. R. (2017). Introduction to hospitality ( $7^{\text {th }}$ ed.). Florida: Pearson Education.

Walsh, K., Enz, C. A., \& Canina, L. (2008). The impact of strategic orientation on intellectual capital investments in customer service firms. Journal of Service Research, 10(4), 300-317.

Warech, M. \& Tracey, J. B. (2004). Evaluating the impact of human resources: Identifying what matters. Cornell Hotel and Restaurant Administration Quarterly, 45(4), 376-387.

Yin, R. K. (2009). Case study research: Design and methods (4th ed.). Thousand Oaks: Sage. 